\title{
The influence of wars on settlement formation and development: The case of Ljubljana, Slovenia
}

Even though there are many historically proven facts about the formation of Ljubljana in literature, a great number of important issues about the origin of the settlement at present-day Ljubljana still remain to be studied in detail. Among the issues that have not been covered in sufficient detail in historical literature as well as in the literature on the urban planning and architecture of Ljubljana are the influences of wars and warfare on location selection and the development of the city. To explore this topic, a thorough and systematic study of strategic and military influences in Europe, the Mediterranean and the
Middle East has been carried out. The development of Ljubljana was carefully studied from prehistory to the Middle Ages, when Ljubljana had a triple settlement core: Old Square (Sln. Stari trg), New Square (Sln. Novi trg) and Town Square (Sln. Mestni trg). The findings help indicate whether Ljubljana's first settlement core (Old Square) was formed by chance or whether this location was selected due to the influence of wars in the area.

Keywords: influences, wars, areas, settlements, locations, urban planning 


\section{Introduction}

Various studies (e.g., Bleiken, 1976; Bogdanović, 1976; Gruden, 1992; Košir, 1993; Reisp, 1998) confirm that great geopolitical changes in various areas (migration of nations included) were always a result of wars or, as the introduction to the Slovenian edition of John Keegan's book (2005: 7-8) states:

\footnotetext{
[W] ar has been one of the significant human activities in all periods of time and cultures and has to be thought of constantly. All arts, philosophies, mythologies, theologies and sciences deal with war. All humanities and natural sciences established in the fragmentation (specialisation) process of human knowledge deal with war and human violence. It would be also difficult to dispute the statement that important technological inventions were primarily created for military purposes and only secondarily for civilian ones ...
}

Because the new military structure usually always assumes the dominant role in the conquered area and changes it according to its interests, wars have always introduced new values and consequently influenced the architecture and urban planning of that entire area. Wars not only caused the downfall of the defeated countries in the territorial sense, but also brought ruin to their traditional cultural achievements and their population. This is also true for Roman Emona, an ancient town in the Ljubljana area that had an important role in Ljubljana's urban development during the Middle Ages (Figure 1; for an overview, see Tomažič, 1937; Stele, 1939; Korošec, 1991).

Wars are processes that constantly occur in world history and continue to have an important influence on various forms of people's lives and their development. In the last 3,500 years approximately 14,500 minor and major wars are said to have taken place across the world. This is why they are considered important factors that influence the development of urban planning and architecture of cities in various ways in different time periods (Tomažičc, 1938; Mumford, 1969; Košir, 1993). The aim of warfare has always been the same. It has been directed towards physical destruction or enslavement of opponents as well as towards the conquest of their land; that is, conquest of their settlements and, later on, their cities. The most research has been carried out on the influence of warfare on settlement development in the Middle Ages, when settlements were reinforced with fortification systems due to constant conflicts among rulers. For this reason, already at that time European courts had skilled military experts for

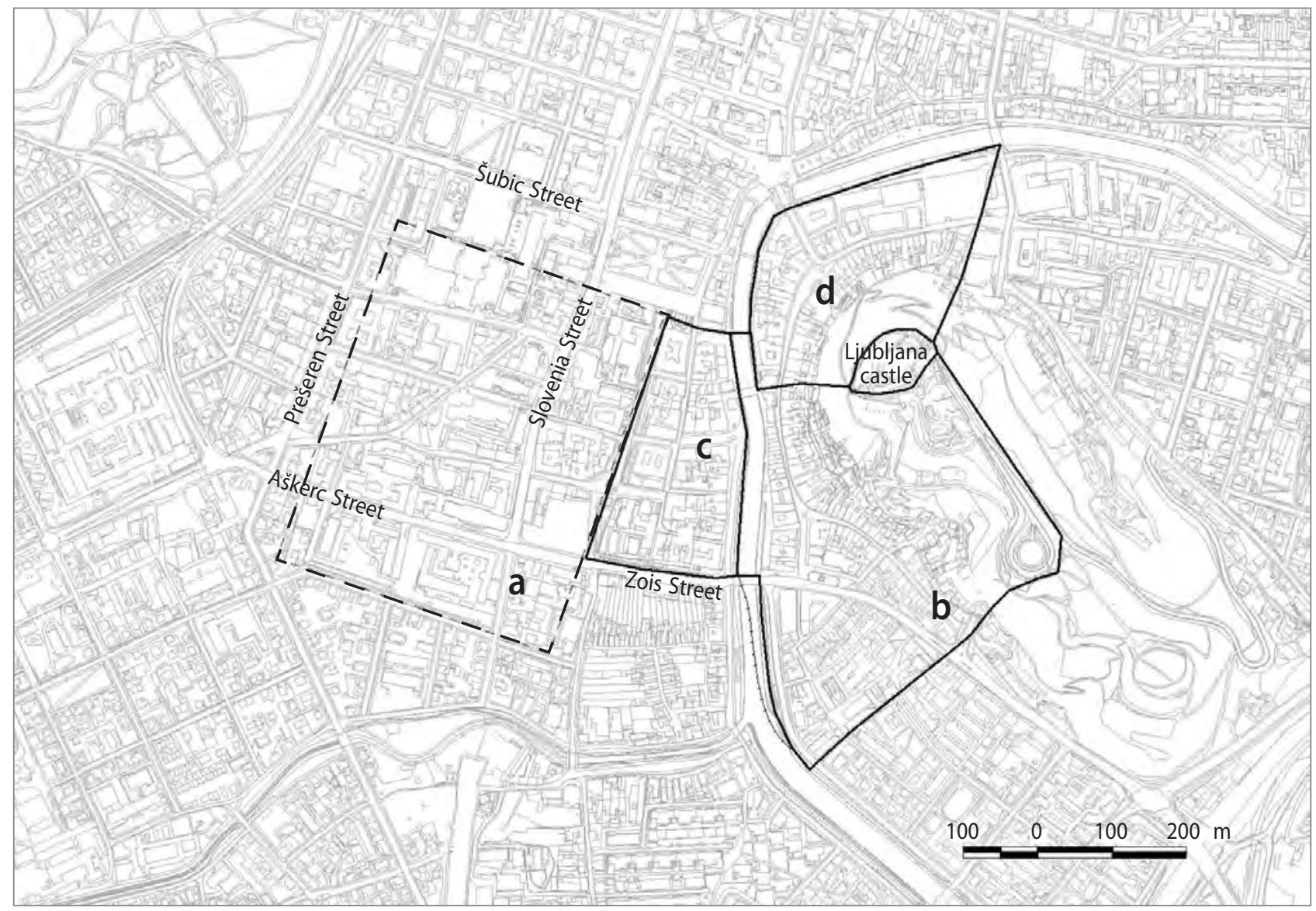

Figure 1: Map of modern Ljubljana's main centre: a) location of Roman Emona; b) the first settlement core of Ljubljana: Old Square (SIn. Stari $\operatorname{trg})$; c) the second settlement core of Ljubljana: New Square (Sln. Novi trg); d) the third settlement core of Ljubljana: Town Square (Sln. Mestni trg; source: Šarac, 2013). 
building fortresses - or, in other words, experts on strategic urban defence. The fact that between 1586 and 1676 the military experts Nicolo Angielini, Giovanni Pieroni and Martin Stier designed the strategic urban plans for the walls around Ljubljana's three settlement cores (Old Square, New Square and Town Square) confirms the influence of warfare on the development of the city in the past (for an overview, see Mantuani, 1937; Tomažič, 1937; Voje, 1984). The settlement cores of old Ljubljana were established at one of the most important strategic points of this part of Europe, called the Ljubljana Gate (e.g., Slabe, 1984; Fister, 1986; Gruden 1992). In terms of warfare, this site had the most important role in a network of settlements and so it was significant for all armies that fought in this area in the past. It is set in a remarkable geographical location: at the intersection of very important land and river routes, on a narrow passage formed by low hills, making it the only possible passageway from the Pannonian Plain to Italy (Puš, 1984; Šašel, 1984). Franc Tomažič (1937) wrote that in the Ljubljana area, on the left Rožnik Hill continues into the Polhov Gradec Hills and the impenetrable Julian Alps, and on the right Golovec Hill expands into various hills and the Dinaric Karst. Ljudmila Plesničar-Gec (1984: 11) states that "all explorers of Ljubljana's oldest history emphasise the city's important geographical location, which was the reason for continuous settlement of its central area during the last four thousand years." The main research question of this article is whether the location of the city's first settlement core on the right side of the Ljubljanica River (Old Square) was selected based on predominantly unknown coincidental location criteria for the development of an urban settlement, or mostly for strategic reasons from the perspective of urban strategic defence.

\section{Research premises}

This article explores the symbiosis of a strategic urban area that has not been previously covered in greater detail in any research even though, in this part of Europe, Ljubljana has a very important geographic and strategic location because of which it has been exposed to influences of various armies. There is extensive historical, archaeological, urban, architectural and other art material about the city, especially about ancient Roman Emona; however, it does not include clear accounts of the influence that wars and strategic principles had on the modern city's urban planning and spatial development. This literature is nevertheless clearly and undeniably important. Without it, it would not be possible to expand the existing knowledge, let alone analyse, discuss and write about this topic. Research and analysis of this literature made it possible to achieve the desired goal: further studies and new findings about the reasons for the settlement and its later development into a city, which was not coincidental, but based on strategic importance. Even in ancient Rome, this location was strategically important, which is why the Roman army was stationed here - with minor intermittent breaks - more than two thousand years ago. The first urban plans of the Ljubljana settlement cores (Old Square, New Square and Town Square) that were prepared by Angielini, Pieroni and Stier provided the motivation and bases for studying the influence of the strategic military aspect.

\section{Method}

This research was a longitudinal historical and qualitative study based on several cases of the influences of wars on the development of individual towns, their urban design processes and the approach to their physical and strategic defence. It explored the period from prehistory to the formation of old Ljubljana's triple settlement core (Old Square, New Square and Town Square). It studied the influences of wars and military activities on the development of prehistoric pile-dwellings and hill settlements, the development of Emona and its road connections, the development of old Ljubljana's settlement cores and city walls, and how this affected the city's urban planning and architecture. In order to find the best solution to the issue, it was necessary to find a way to present urban changes as vividly as possible over time in the area of today's Ljubljana as well as in Europe, the Mediterranean and the Middle East. Town layouts - the basic element used for describing and explaining in architecture and urban planning - were used for this purpose. This is because layouts provide the most authentic picture of architectural and urban achievements as well as development processes in a particular geographic area. By studying layouts across time and space, historical, archaeological and other data were obtained that each in their own way reveal past events and their development processes. Because strategic influences and strategic urban defence have not been sufficiently covered in literature on urban planning and architecture in Ljubljana, all important features relating to strategy in a wider area were analysed and compared, and new conclusions were drawn based on new findings. These processes took place at the basic levels at which settlements and cities are built. They are the easiest way to study urban development and changes as well as analyse past achievements in the area of today's Ljubljana and compare them with other aforementioned areas. Therefore they are referred to as layouts across time and space (Figure 2).

Layouts across time and space are actually horizontal cross sections in a particular time and space that are layered one upon another and make it possible to compare concurrent historical, strategic, architectural, urban and other achievements in a broader area with those in Slovenia. The study also used other technical terms that enabled the simplest and clearest possible presentation of how events in the human past developed, including the strategic conditions in various times and 


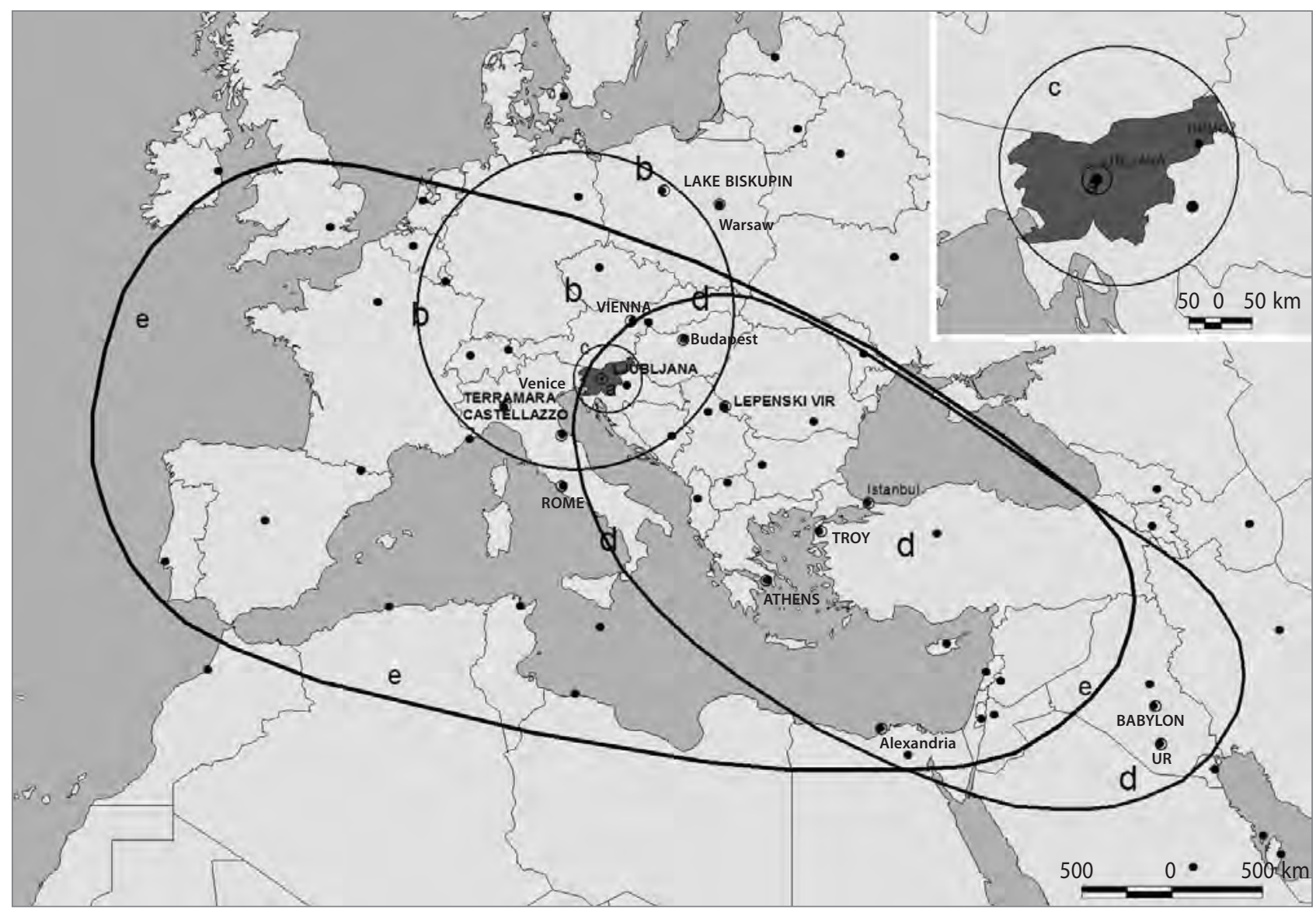

Figure 2: Layouts across time and space of a) Ljubljana; b) Europe; c) Slovenia; d) the Mediterranean and the Middle East and e) the Roman Empire (source: Šarac, 2013).

spaces. These terms included the following: 1) strategic urban defence, which is a combination of strategic, urban-planning, architectural and other ideas and skills that people used to physically protect themselves from the aggression of war in the past and 2) strategic influences, which include military experiences with offense and defence in the development of settlements that were continually transferred between various geographic spaces and established themselves under new circumstances. Here not all segments of urban planning or history were examined in detail, but only those connected with wars and strategic urban defence to such an extent that this can still be identified today. Armies and wars have never had a fundamental connection with urban planning, considering that they deal with the destruction of mankind and the values it has achieved, and urban planning deals with the basic principle of planning human lives in space. Nevertheless, they have important common ground that cannot be avoided and that relates to various factors that are referred to here as strategic urban defence. It was established that, during historical development, human self-protection or strategic urban defence was shaped in different ways. It especially depended on natural conditions, individuals' ingenuity and creativity, their weapons and other resources they used to defend themselves or were attacked with. From the strategic and urban-planning standpoint, strategic urban defence includes the following: 1) selecting a location for the settlement that needs to be in a place that the opponent finds difficult to access, 2) outlining and building the protective ring around the settlement and 3 ) building defensive moats around the ring as well as everything else connected with urban and strategic activity.

\section{Research results and discussion}

By studying history vertically (i.e., across time and space), or with the analysis and comparison of the aforementioned layouts across time and space, it was established that strategic urban defence had an important influence on the spatial and urban-planning development of various cities, including Ljubljana. Based on the findings, it was established that Ljubljana's first settlement core (Old Square) was established precisely under strategic influences - that is, according to the principles of strategic urban defence. It was also discovered that the settlement was formed in early feudal times; that is, in the migration period, and that Slovenians bearing arms established it as a farming and military settlement. It was established that Ljubljana’s third settlement core (Town Square) also developed based on urban strategic defence, although under different historical circumstances. 


\subsection{Analysis and comparison}

Historically established facts show that ever since the first human encroachment into the environment (in prehistory) that is, from the first established settlements onwards, when people stopped looking for natural shelters instinctively and deliberately started building them and permanently living in them - people have also been consciously thinking about protection and defence. This safety planning actually resulted from their fear of a violent death, which is common in military conflicts. Although people found resolution in the imaginary world in pagan and later religious beliefs and accepted biological death as the beginning of an afterlife (Puš, 1984), they constantly had to protect themselves from a violent death. This is why they lived in communities and used all natural and physical resources available for protection. One such example of early permanent human settlements close to Slovenia is the Lepenski Vir archaeological site near the Danube at Đerdap, Serbia, dating from the fourth millennium BC (Maksimović, 1972; Bogdanović, 1976). In this regard, Fedja Košir (1993: 26) also mentions that "it is not illogical that in an agglutinated cluster the most important elements are those providing protection. To a relatively reliable extent, this is already provided by compact construction culminating in the mythical chaos of a labyrinth. Compactness (agglutination) especially makes it more difficult to find one's way because only the locals know how to 'communicate' in such settlements."

Even the prehistoric layout of the modern Ljubljana area displays a paradoxical situation. It shows that in those times there were no settlements close to the natural intersection of important traffic routes (e.g., the Amber Road), which were used for material and cultural exchange and led from the Pannonian Basin to the Mediterranean and from the Balkans to western Europe (Gruden, 1992; Plesničar-Gec, 1984; Puš, 1984; Vilfan, 1984). Based on this it could be concluded that at that time, most likely due to strategic reasons, the intersection in the lowland of the Ljubljana Basin was not particularly attractive or suitable for settlement. In fact, this proves that at that time people in this area did not yet have enough experience with strategic urban defence to risk building and developing a settlement in the lowland of the Ljubljana Basin, where there were the best conditions for agriculture, animal husbandry and so on. For strategic reasons and under the influence of such strategic experiences from elsewhere in Europe at that time, people built their settlements far from the traffic intersection that is, on the outskirts of the Ljubljana Marsh, which was still a lake around 2000 BC (Figure 3a).

In addition to the pile-dwelling settlements in the marsh, smaller settlements by the Little Canal (Sln. Mali graben) in Prule and elsewhere can be defined as the oldest known settlements
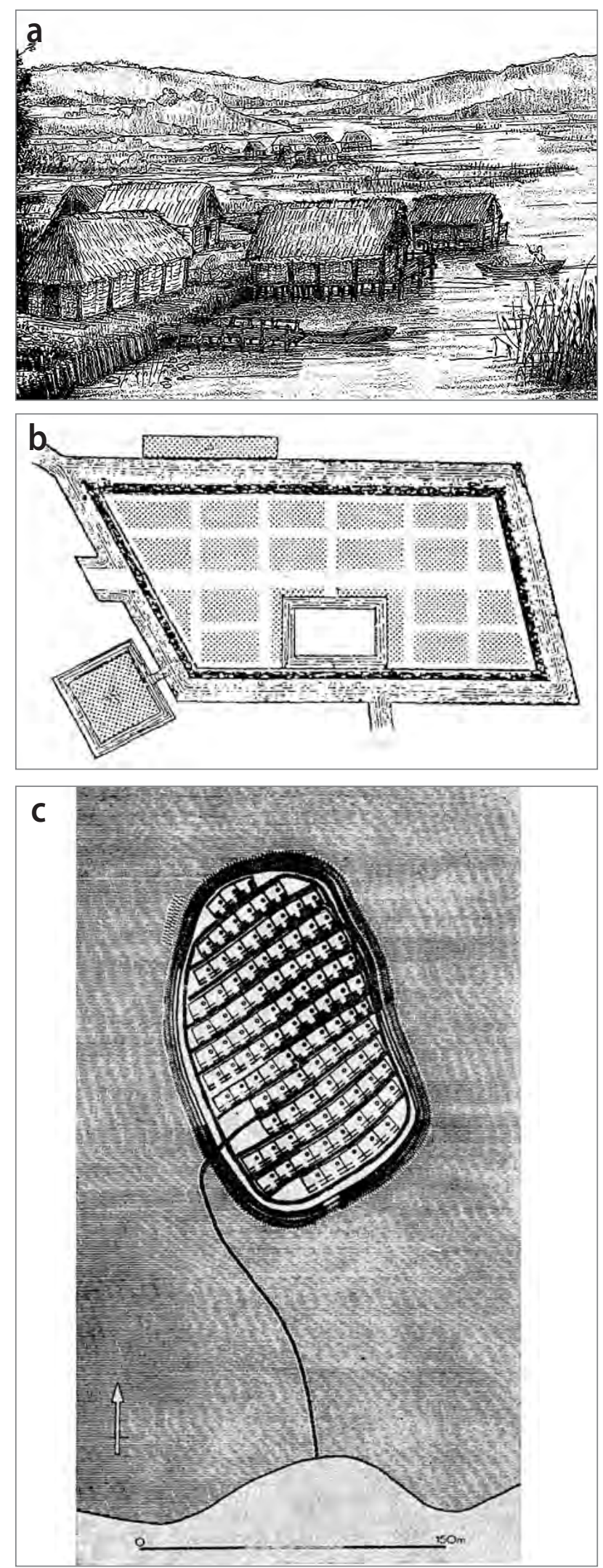

Figure 3: a) Pile dwelling settlement in the Ljubljana Marsh, reconstruction; b) pile dwelling settlement of Terramara Castellazzo in Italy, second millennium BC; $\mathrm{c}$ ) an island settlement on Lake Biskupin, sixth to fifth centuries BC (sources: a) Fister, 1986; b) Košir, 1993; c) Maksimović, 1972). 


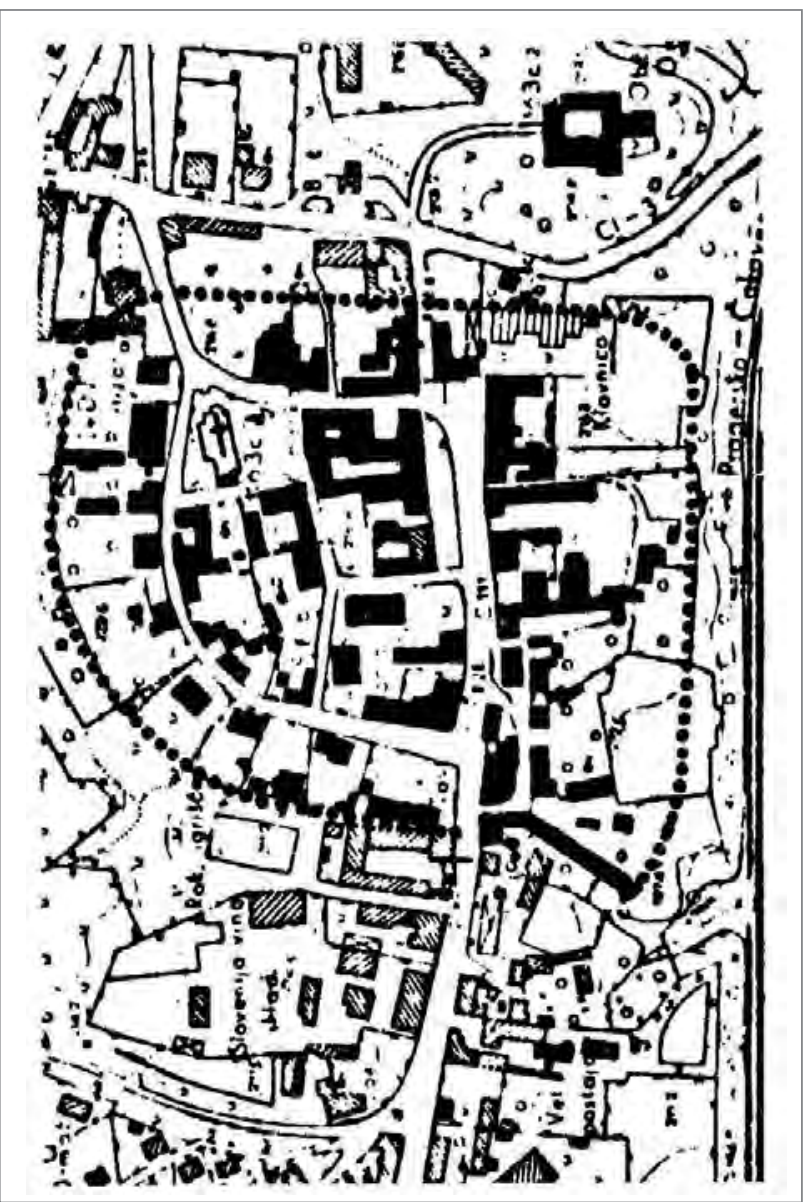

Figure 4: Layout of the prehistoric town of Ormož around 1000 BC (source: Fister, 1986).

in the Ljubljana area (Stele, 1939). Tatjana Bergant (1984) found that the special characteristics of the Ljubljana Marsh determined the distinctive architecture of the pile-dwelling settlements, which was probably already differentiated by wealth, and which probably also confirmed the development of a military aristocracy. A number of similar pile-dwelling settlements were also established elsewhere around Europe (Switzerland, Italy, western Austria, eastern France, the Sava Valley in Croatia, etc.) at the same time as in Slovenia or before, but they implemented the principles of strategic urban defence in a completely different way. The best-known pile-dwelling settlement is Terramare Castellazzo in Italy, established in the Bronze Age, around $2000 \mathrm{BC}$ (Figure 3b). According to some sources that have not been well studied, in addition to being surrounded by a wooden palisade, the inner part of the settlement supposedly already had a proper design with interior structures. In the Late Iron Age, in the sixth to fifth centuries $\mathrm{BC}$, an island settlement was established on Lake Biskupin in Poland (Maksimović, 1972; Košir, 1993). In addition to being built on water, it followed the principles of strategic urban defence and was thus surrounded by protective walls that were built out of three types of logs and filled with mud (Figure 3c).
On the hills around today's Ljubljana, in hard-to-reach areas, spontaneous clustered settlement formations were established around $1300 \mathrm{BC}$ (Gruden, 1992).

The fact that strategic urban defence was considered when settlements were being built is also evident from the findings based on layouts across time and space of a completely different part of today's Slovenia. The settlement close to Ormož was established around $1000 \mathrm{BC}$; that is, almost a millennium after the pile-dwelling settlements in the Ljubljana Marsh and 300 years after the settlements on Castle Hill (Sln. Grajski grič), and it is considered one of the first urban settlements in Slovenia. Peter Fister (1986) writes that it was located on a large natural plateau above the Drava River and that it measured about 300 by $400 \mathrm{~m}$. Supposedly it was fortified with a $5 \mathrm{~m}$ embankment that was reinforced with a wooden palisade and a $6 \mathrm{~m}$ ditch. On the inside it was richly designed; the wooden houses were connected by perpendicular paved roads, and the settlement was even larger and more complex than the later medieval town. From the standpoint of strategic urban defence, this lowland settlement is interesting because it had not only an embankment and a wooden palisade that surrounded the entire settlement, but also a deep ditch (Figure 4).

An analysis of large prehistoric layouts shows that settlements in eastern Europe, the Mediterranean and the Middle East were generally more developed, advanced and at a higher level of civilisation and cultural achievement than those in Slovenia and western Europe. At the time of the pile-dwelling settlements in the Ljubljana Marsh and other similar settlements around Europe, significant complex architectural compositions were built in Egypt (2778-2263 BC): grandiose temples in Luxor and Karnak, and the pyramids of Khufu, Khafre and Menkaure confirm the existence of an imaginary world and that people believed in an afterlife. They also built immense cities: Thebes, which was presumably built on the right bank of the Nile among the aforementioned temples, measured between 12 and $15 \mathrm{~km}$ long and was the seat of the pharaohs; Kahun (nineteenth century BC), a city with a rectangular outline and a size of approximately 10 ha that was surrounded by a brick wall and established in order to provide housing for the workmen that constructed the Pyramid of Lahun; and Akhetaten (1400 BC), a city built as a new political and religious capital of Egypt (Maksimović, 1972; Košir, 1993).

The situation was somewhat different in Babylonia in $3000 \mathrm{BC}$. Differences can be seen not only in the architecture and urban planning of the cities that were already planned at that time, but also in the highly developed sense for strategic urban defence. Their cities were mostly built next to rivers and main roads or crossroads. They had terraces used for defence and as lookout points that were built on several levels to protect them 
from floods and provide a mental divide between the divine and the human. On these terraces, important buildings (temples and courts) were erected that could be reached by stairs. Already at that time, cities had a town sewer system and water supply in place, which confirms a high level of general culture and engineering. When these cities were built, strategic urban defence was taken into account and also constantly improved due to continuous warfare. From this point of view, an especially interesting example is the city of $\mathrm{Ur}(2300-2200 \mathrm{BC})$, which already had a population of roughly half a million. In addition to the city walls and the ditch encircling this oval city, there was also an additional inner defensive wall with a ditch surrounding a rectangular temple complex and the emperor's palace (Figure 5a). In some ancient cities from this period (Assur and Nineveh), the emperor's palace was located at the edge of the city walls, right next to the river, probably because of better chances for an easier escape (Maksimović, 1972; Košir 1993).

Especially important in this group of cities is most definitely the newly designed city of Babylon (seventh-sixth century BC, around 200,000 inhabitants), which was considered the centre of the world at that time. This city is known not only for its world wonders such as the terraced Hanging Gardens and the $90 \mathrm{~m}$ high ziggurat known as the Tower of Babylon, but also for its attractive urban planning and elements of strategic urban defence. These structures are also interesting because they were established almost concurrently with the key urban-planning movements that indicate almost a complete metamorphosis in construction in the whole of Europe; they might even serve as a role model for these processes. The city was actually not new because King Nebuchadnezzar rebuilt it after the annihilating victory over the Assyrians. It was located on both banks of the Euphrates and had a relatively rectangular shape (Figure $5 \mathrm{~b}$ ). It was divided into quadrants connected in a network of straight streets that led to the procession street, which in turn led from the grand main entrance with double walls through the new part of town on the right (around 1,600 by 1,600 m), where a bridge over the Euphrates connected it with the old part of the town on the left. The entire city was surrounded by double walls and deep moats. Strategic urban defence was thus very important for the city to develop normally and defend itself from the armies that it was constantly exposed to - until it was conquered by the Macedonian leader Alexander the Great and burned down in $330 \mathrm{BC}$.

When Alexander the Great rose to power, the Hellenistic period and its colonial expansion began. There were important changes in architectural and urban composition as well as in the framework of new compositional concepts of cities, which are also believed to have arisen due to concurrent examples from the ancient East. Košir (1993: 67) wrote about
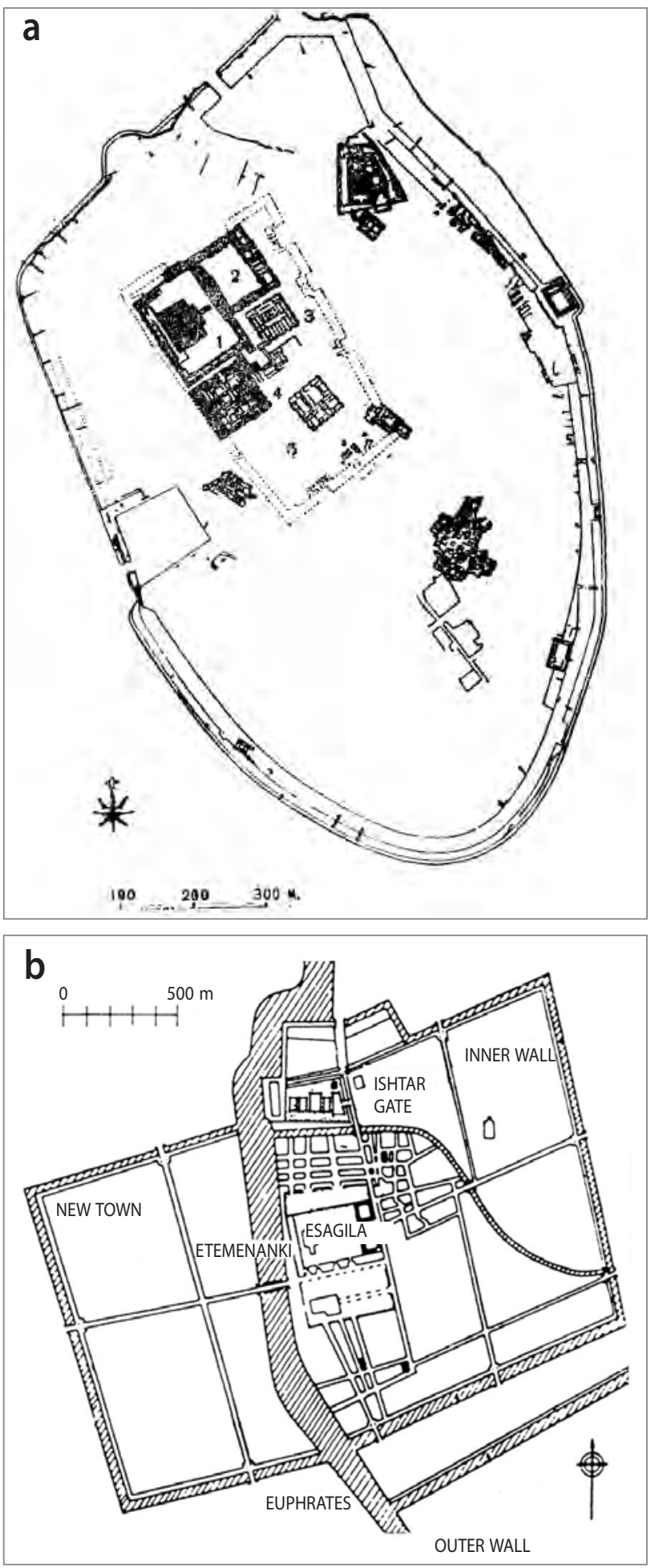

Figure 5: a) Layout of the Sumerian town of Ur, 2300-2100 BC; b) layout of Babylon, sixth century BC (sources: a) Maksimović, 1972; b) Košir, 1993).

these changes: "It would be difficult not to use all of this as a model. The gigantic mosaic of the state of Persia was later actually an incubational 'greenhouse' where victorious Hellenism developed and flourished - thus beginning the second 


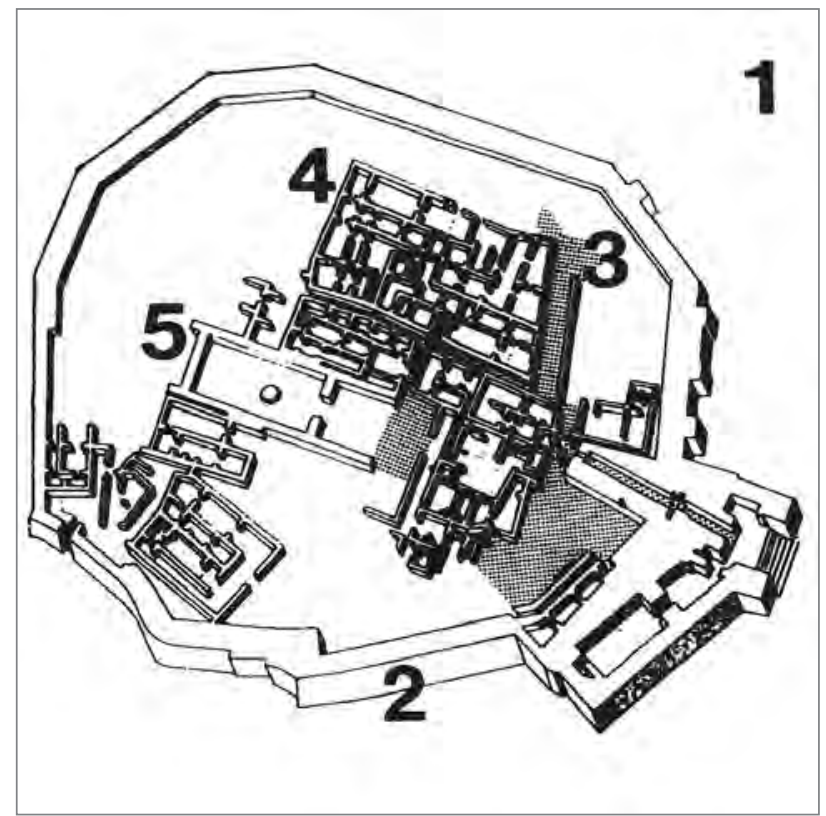

Figure 6: Spatial elements in the reconstructed archaeological ground plan of Troy: a) location; b) protective ring; c) hierarchically structured communication system; d) the fabric of urban construction; e) architecture of "special importance" (source: Košir, 1993).

phase or the so-called classical phase of the slave-ownership system." The unsystematically built communication network with curved streets of that time was replaced by a disciplined and standardised orthogonal raster. This reached its peak in the classical age, when structure and contour were tuned into a "pure" form and spread to western Europe, where they were adopted by Roman urban planning, which was a synthesis of the whole of antiquity. Strategic urban defence became a very important factor when choosing a location for building cities according to the new system. Settlements were established on places that were considered strategically most secure; that is, on the coast. Such towns include Piraeus, the largest Athenian military and trade port, which was discussed by the greatest minds of that time, such as Aristotle, as well as Alexandria, which is located on the coast between two lagoons and was favoured by Alexander the Great (Maksimović, 1972; Košir, 1993).

Among the elaborate Mediterranean urban-planning achievements, Troy should be explicitly mentioned. There is rich archaeological evidence of the city (2300-1100 BC), whose inner structure was constantly reshaped until a town was finally shaped with all the urban elements, which at that time symbolised a city regardless of its size and had more to do with its content (Bogdanović, 1976). The reconstructed layout of Troy by Košir (1993) includes five accentuated spatial elements that suffice for an explanation and comparison in this article. They include: 1) the location, 2) a protective ring, 3) a hierarchically structured communication system, 4) the fabric of urban construction and 5) architecture of "special importance." Hence it can be concluded that location (actually its selection) and the protective ring are the essential elements of strategic urban defence, as was already evident in the examples of the Babylonian cities and pile-dwelling settlements in Europe. Thus these strategic urban elements of the layout are used in further analyses and comparisons as a clear example of an urban unit (Figure 6).

Compared to the Slovenian pile-dwelling settlements (2000 BC) and the settlement of Castle Hill (1300 BC), Troy is geographically far away and had a different cultural development and structural content of the settlement. However, from the perspective of safety or strategic urban defence, it can be concluded that all of them share similar elements. The location selection for the settlements (evidence of urban-planning activity) is the main element of strategic defence of any human change in the environment. Pile-dwelling settlements were built on water and other settlements on hills. The second element of strategic urban defence (i.e., the safety provided by the settlement's protective ring) was represented by water in the pile-dwelling settlements and by embankments of tamped clay in the settlements on hills. This shows that in their historical development people always tried to protect themselves as best as they could by choosing locations for their settlements that included the largest obstacles for the invaders and thus protected the settlement and its inhabitants as much as possible.

\subsection{The first systematic urban-planning changes on the site of today's Ljubljana}

The site of today's Ljubljana experienced its first systematic (i.e., urban-planning) changes about 2,000 years ago, when Roman soldiers from the Eleventh Apollonian Legion marched through the Vipava Valley and occupied this place. It was the Roman legionnaires that first realised how strategically important this geographic location was (Tomažič, 1938; Slabe, 1984; Fister, 1986; Gruden, 1992); they occupied it and built a town called Emona here with the help of troops that are still called the "engineer troops" today (Fister, 1986). One might say that Emona was built following a typical Roman design, which was defined by a strict rectangular shape in a size of 523.6 by $435.5 \mathrm{~m}$ and which the Romans normally used and adapted to build camps for their legions, such as Castra Vetera on the Rhine, Novaesium in the Rhineland, Vindonissa in Switzerland and Vindobona in Vienna (Schmid, 1941). The location for building the town was selected based on all of the eastern civilisational and strategic experiences gained up to that time. However, according to the legend of the Argonauts, the settlement of Emona already existed here before the arrival of the Romans (for an overview, see Šašel, 1984; Gruden, 1992). The first requirement of strategic urban defence was a safe loca- 
tion: the confluence of the Ljubljanica and Gradaščica rivers was chosen for its natural conditions, which were primarily used for protection and secondarily for other, later uses. The second requirement of strategic urban defence was the protective ring surrounding the camp, which was comprised of a stone wall 6 to $8 \mathrm{~m}$ high and 2 to $4 \mathrm{~m}$ wide. It had twenty-six towers, four main entrances (north, south, east, west) and ten side entrances, which were later sealed for safety reasons (Slabe, 1984). An indispensible part of strategic urban defence was also the moats surrounding the walls, which were dug out from the outside. A special characteristic of Emona and other Roman settlements from this period was that they were oriented according to the cardinal directions (i.e., east-west and north-south); these also defined the town's main streets: Decumanus maximus, or present-day Roman Street (Rimska cesta, east-west), and Cardo maximus, or present-day Slovenia Street (Slovenska cesta; north-south). The main town entrances connected roads coming from the direction of Rome, Via Iulia Augusta (present-day Trieste Street, Tržaska cesta), from the Balkans (present-day Karlovac Street, Karlovska cesta), from the Pannonian Plain (present-day Slovenia Street and Vienna Street, Dunajska cesta) and from the northwest (present-day Klagenfurt Street, Celovska cesta). When it was finished, the inner part of the camp had an urban character. It was divided into urban rectangular and square housing units (insulae) with a perpendicular street network and a main forum (i.e., the town square), which was an innovation in urban planning compared to the cities of the ancient east. In fact, the Roman town of Emona is a prime example of all urban-planning and architectural elements of ancient civilisation known until then. After Christianisation, Emona was also the seat of a diocese (Bratož, 1984; Šašel, 1984). Although Emona was destroyed by the Hun army around 452, its diverging roads established by the Roman army two millennia ago still represent the framework of the main roads in modern Ljubljana (for an overview, see Tomažič, 1937; Vilfan, 1984). Later internal problems of the Roman Empire, and constant battle for power and wars with the Huns, Goths, Lombards, Franks and Slavs led to the downfall of the Western Roman Empire (Ciglenečki, 1992; Gruden, 1992). With the downfall of the empire, the system of slave ownership was also brought to an end, the migration period started (fifth to sixth centuries), Christianity in this area collapsed and a new social system in Europe known as feudalism was established. According to Nada Bogdanov et al. (1967), power and land as the material foundation of feudalism were vertically divided between the lord (emperor) and the vassals (feudatories) or honoured soldiers. Trade was no longer carried out with money, but through barter with natural goods. If necessary, the feudal lords had to defend the interests of the emperor with their soldiers (peasants) drafted from settlements on their fiefs. In early feudalism, ordinary

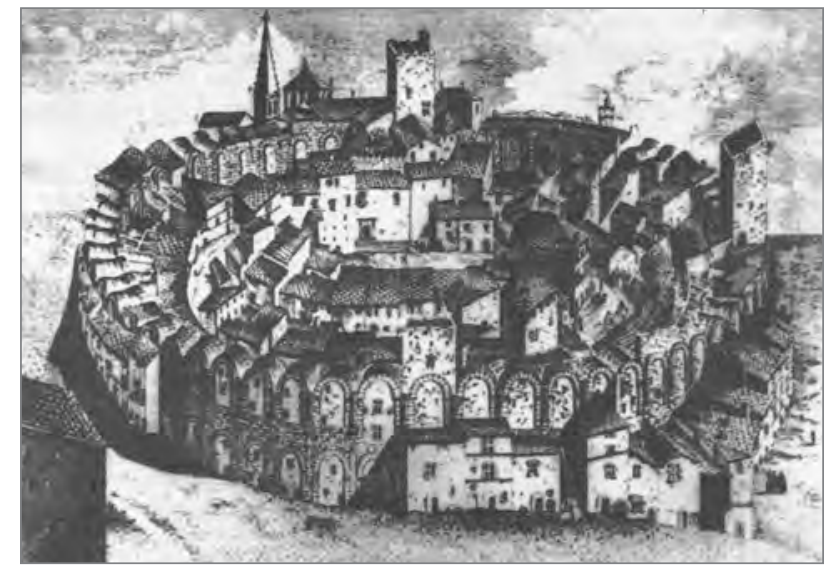

Figure 7: View of the medieval town core of Arles: an arch of the Roman amphitheatre converted into a medieval town wall (source: Košir, 1993).

peasants were no longer slaves, but members of a subordinate class. They had to cultivate the land, pay taxes in natural goods and as soldiers unconditionally fight for their lord or supreme ruler, although this last condition did not apply to Slovenians until approximately the ninth or tenth century (Vilfan, 1984).

\subsection{Formation of Ljubljana's first settlement core (Old Square)}

The layouts from between the sixth and twelfth centuries are particularly interesting for this article because they show that an empty space developed in the area of today's Ljubljana. This was the time when Slovenians most likely began settling this area, making the early Middle Ages the era of Slovenian consolidation (Sivec, 1984; Gruden, 1992). Because this time period was undocumented, the "arrival" of the Slovenians to this area is very controversial because it was accomplished by local wars for land and power. In general, after the downfall of the Western Roman Empire and the Hunnic Empire after Attila's death in 453, historical events were extremely turbulent all over Europe. It would be incorrect to assume that Slovenians occupied the new area in a friendly manner. Above all, they arrived in the area of today's Ljubljana as colonists, who are historically well known to have always arrived in the new lands through force of arms (Tancik, 1971; Gruden 1992). Josip Gruden (1992: 40) wrote the following about the Slovenians: "Here our ancestors do not come across as a peaceful nation, which only engaged in agriculture and animal husbandry, but as strong and fierce people that boldly attacked powerful countries and conquered new lands with their weapons." The objective of the arrival was clear. The colonised area that had been continuously populated over the past four millennia (Plesničar-Gec, 1983; Kos, 1985; Gruden, 1992) first had to be "cleared" (in military terminology) with the use of force and weapons so that a new settlement could be established, from which today's Ljubljana developed much later on. So why did the Slovenians decide 

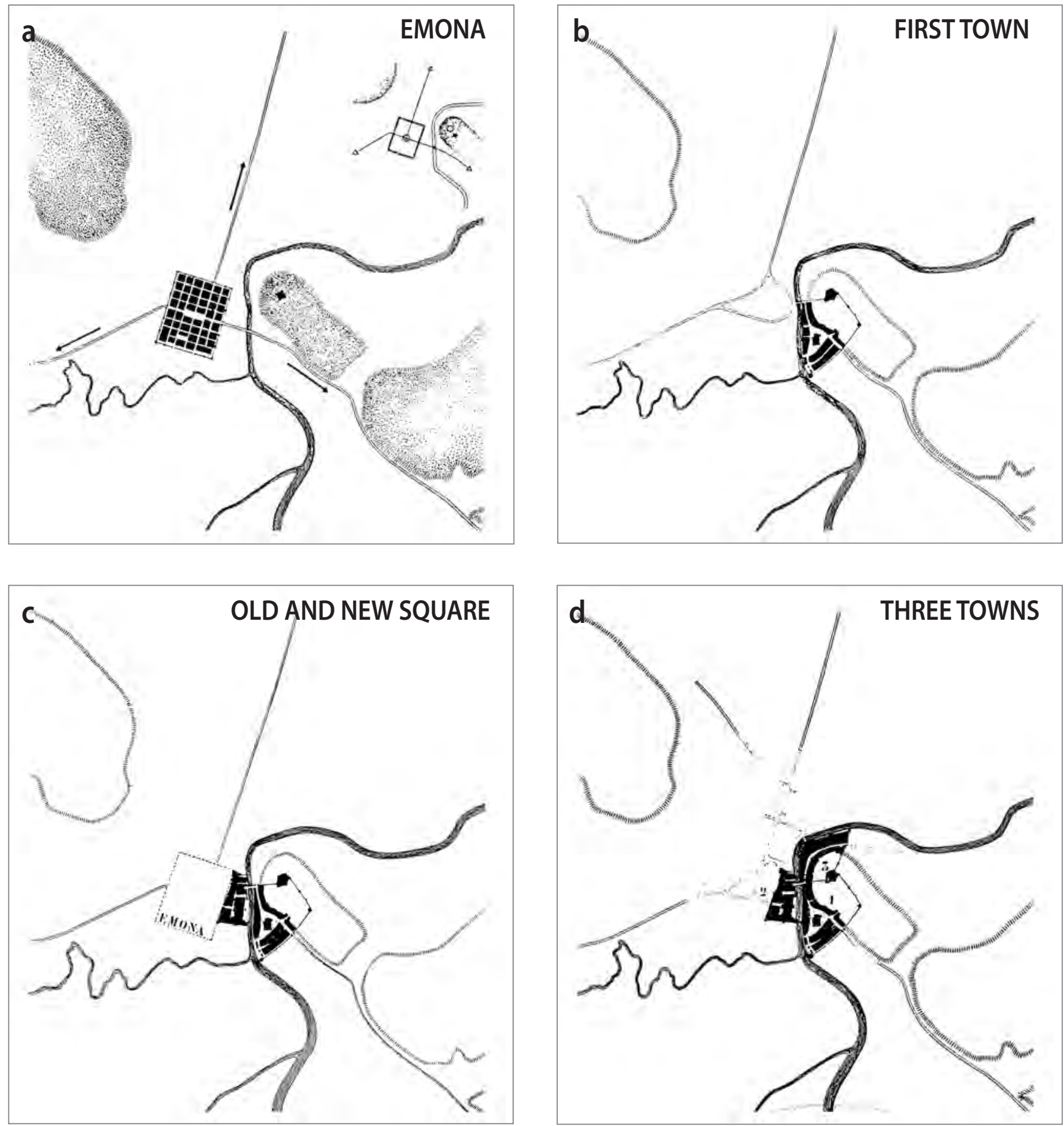

Figure 8: a) location of Roman Emona; b) location of Old Square; c) location of Old Square and New Square; d) the final form of the three settlement cores of Ljubljana (Old Square, New Square and Town Square; source: Stele, 1939).

to choose this location for their settlement when many other possible locations were available? Historical evidence shows that they did not restore the ruins of Emona even though they provided the best chances for accommodation: construction material and Roman family houses with the achievements of civilisation of that time such as a water supply system, sewer system and floor heating. They probably decided against this because the group (Sln. $\check{z} u p a$ ) that settled in this area was small or because it led an entirely different way of life that was in complete contradiction with the confined system of a Roman house. In fact, the $\check{z} u p a$ was the first Slovenian political unit and consisted of a group of relatives that lived together in a particular area (Gruden, 1992). The Slovenians had no desire to renovate the dwellings of their predecessors or adopt their living habits, but new economic relations and opportunities for better defence caused individual towns elsewhere in Europe to shrink; these towns were established on areas of past Roman settlements (Florence and Bologna or amphitheatres converted into fortified settlements, such as the ones in Périgueux, Tours, Nîmes and Arles; Figure 7; Košir, 1993). 
The case of Emona in fact illustrates a historically proven fact: the Slovenians avoided Roman towns and preferred to build their own settlements in the vicinity (Figure 8a). One such location for a new settlement in Emona's vicinity was the plain at the intersection of important trade routes near Ajdovšcina with a tradition several millennia long, where Kavarna Evropa 'Europe Cafe' (see Grafenauer, 1963; Vilfan, 1984) now stands. This apparently provided the best conditions for their activities: agriculture, animal husbandry and so on. As already mentioned, living on flatlands in prehistoric times was not safe unless all the principles of strategic urban defence were guaranteed in advance. Thus, if the Romans as the greatest power of that time followed this strategy and established Emona at a safer location in the south - that is, at the confluence of the Ljubljanica and Gradaščica, instead of at the intersection of the trade routes - then it is not surprising that the Slovenians also avoided this location. They had no interest in rebuilding the aforementioned settlements in the marsh or on the hills. Instead, these Slovenians or armed founders of the future Ljubljana selected a completely new location for their settlement that had not been continuously populated. They selected a strategically safe location away from the crossroads that did not limit their collective way of life or their collective farming activities on the fields close to the settlement. As is still evident today, they selected a location that, in addition to the aforementioned characteristics, also had the elements of strategic urban defence, which were adapted to the weapons and tools they used for offence and defence at that time. They therefore settled on the right bank of the Ljubljanica; that is, on the side opposite the ruins of Emona not so far away. Anton Melik (1929-1930) believed that this settlement was made on the trails and the foundations of Roman roads, but the regular design of the settlement's layout confirms that this location was not populated before then. Considering that they had weapons, they most probably decided on this site based on their strategic experience and thus chose it because it was difficult to access and compared to all other locations discussed so far it also had all natural barriers (a river, a hill and a marsh). As elements of strategic urban defence, these barriers offered strategic safety and good opportunities for retreat in case of threats from various directions, which was a special characteristic of Slovenian settlements at that time (Fister, 1986; Figure 8b).

An important, so far unmentioned part of the research is the castle on the hill above the settlement. It is historically known that the Slovenians in this era were unable to form a uniform military organisation under their nobility that would protect the entire conquered and colonised area, which is why they became subordinate to various foreign feudal conquerors of the area (Lombards, Franks, other Germanic peoples etc.) as well as to the church authority that later Christianised them (Kos, 1985; Grafenauer, 1963). With their way of life and especially their method of cultivating land in a group and not individually like the Romans (Fister, 1986; Gruden, 1992), they went far back in time - that is, to the time before the arrival of Romans. The castle above the settlement may thus not have been owned by local lords but was probably taken over by foreign feudal lords (Šenica-Pavletič 2005). From the historical point of view, the question whether the castle and the settlement were formed at the same time or separately (see Vilfan, 1956) is very interesting. However, the most important fact for this analysis is that they were both built according to the principles of strategic urban defence.

\subsection{The formation of Ljubljana's second settlement core (New Square)}

When the first settlement core of Old Square outgrew its spatial, urban, church and demographic capacities in a slow development process over several centuries, it started to expand. That a process of transformation can be slow and lengthy can be seen even today in modern Ljubljana’s Šš̌ka district, where there are still farmhouses in the centre of the settlement with roots going back to the thirteenth century. This process was probably just as slow as the religious reform of Slovenian pagans praising the lord of the universe, who caused thunder and lightning (Gruden, 1992). Thus Old Square witnessed a structural and religious reform of the peasantry and a new type of population was established that, in addition to agriculture and fishing, also started to engage in trade and craftsmanship (Cevc, 1984; Gestrin, 1984; Simoniti, 1984; Žontar, 1984). One would expect that the urban Old Square would spread out on the Ljubljanica's right bank towards Prule or towards today's Town Square (Tomažič, 1937). However, this was not the case. In the thirteenth century, Old Square started to spread out on the Ljubljanica's left bank, where the second settlement core, New Square, was established (Kos, 1955). This was located between the river and the remains of the Emona town walls; that is, in an unprotected location, which was in complete contravention of the principles of strategic urban defence (Figure 8c). If all historical arguments about the urban development of New Square are taken into consideration, the most probable reason for establishing it at this location was the relatively peaceful period in the area that came after the lengthy and violent wars for power among the feudal lords in the thirteenth century (Valvasor, 1984; Simoniti, 1990). The fact that New Square developed as a more relaxed urban trade settlement that was home to wealthier townspeople and noblemen also confirms the belief that at that time this area was at peace, which is why the new settlement did not adhere to all the principles of strategic urban defence. 


\subsection{The formation of Ljubljana's third settlement core (Town Square)}

Ljubljana's urban development did not continue on the Ljubljanica's left bank, which was more suitable for construction that is, with the continuation (expansion) of the settlement core of New Square. Instead, in the fourteenth century its development again took place on the Ljubljanica's right bank between the river and Golovec Hill (Kos, 1955). From the urban standpoint, this move to the right bank was illogical; however, it was probably not coincidental but a consequence of strategic urban defence that was already very important for establishing the first settlement core of Old Square (Šumi, 1953). Namely, this move coincides with the wars that led to the downfall of the Byzantine Empire due to conflicts with the Ottomans, who expanded throughout Asia Minor under the leadership of Sultan Osman (1288-1326; Bleiken, 1976; Javornik, 1998). Later historical events confirm that at that time, from the standpoint of strategic urban defence, the location selection for the third settlement core was appropriate (Figure 8d). The Ottomans began their conquests in the Balkans with victories on the Gallipoli Peninsula in 1354 under the leadership of Sultan Orhan (1326-1359), at the Maritsa River in 1371 and in Kosovo in 1389 under the leadership of Sultan Murad, and thus finally made their way to central Europe to conquer Vienna and Venice and consequently also Ljubljana. Changes in the defence system of Ljubljana (Old Square, New Square and Town Square) did not occur until 1415, when the Ottomans first appeared in the area. The general understanding of strategic urban defence reached a decisive point in 1416, when the town walls began to be reinforced. After 1469 , the Ottoman raids from Bosnia continued for no less than 200 years and thus, in the framework of strategic urban defence, the most attention was devoted to building and reinforcing the town walls, as Milko Kos $(1955: 35,36)$ wrote:

\footnotetext{
This is undoubtedly connected with efforts to protect Ljubljana as much as possible from the dangers of war, which were greater in the fifteenth and sixteenth centuries than in the first centuries of the town's existence. A series of measures were adopted out of concern over the threat of the Ottomans: in 1471, houses and barns on the outskirts and outside the town walls were demolished so that, when coming to Ljubljana, the Ottomans could not find shelter in them; for the same reason the Augustinian monastery and church outside the Hospice Gate (Sln. Špitalska vrata) were demolished (in 1494), as well as the Fortification Church of Mary, Mother of God and St. John's Church on the outskirts (in 1554); and in 1499 the entrance by the commandery of the Order of the Teutonic Knights was sealed.
}

In the feudal wars for the conquest of the fortified feudal castles and the seizure of power, the town walls were not particularly important for the protection of the inhabitants in the conquered towns because the lords usually did not kill the townspeople and thus not all towns were fortified (Valvasor, 1984). However, in wars with the Ottomans, the situation was completely different (Tomažič, 1938; Simoniti, 1990). The elements of towns' strategic urban defence were very important for protecting the inhabitants because in the case of a conquest the Ottomans would kill or enslave the townspeople as well as burn and destroy the town. In the Middle Ages, when the Ottomans appeared, all three of Ljubljana's settlement cores (Old Square, New Square and Town Square) were surrounded by walls (see Zwitter, 1929-1930). Precisely the walls' shape confirms that Ljubljana developed from three settlement cores, of which each was a separate fortified unit (Kos, 1955). According to the principles of strategic urban defence, this triple fortress was also protected with ditches and further connected with forts on the slope of Castle Hill. Because the area of the settlements was restricted by the defensive wall, the narrow plots of land were used for streets with multistory houses pressed up against one another (Šumi, 1953).

\subsection{Military experts in fortifying Ljubljana's triple settlement core (Old Square, New Square and Town Square)}

Based on the data available today, it can be concluded that, from the standpoint of strategic urban defence, one of the oldest and most detailed fortification plans of Ljubljana's town walls was designed in 1586 by the Italian military architect and constructor of fortifications, Nicolo Angielini, who was commissioned by the Viennese court. The two versions of Angielini's design most likely prove that the town walls were fortified following this design. Angielini's watercolour painting from that time displays a detailed account of the entire town walls, major buildings and the rest of the town, but does not display anything located outside the town walls; for example, Ljubljana's outskirts. Although the first Ottoman raid in 1529 under Sultan Suleiman the Magnificent (1520-1566) to conquer Vienna was not successful, they did not give up their efforts to do so. Quite the opposite! The hundred-year war between the Habsburg Monarchy and the Ottoman Empire began, during which the Ottomans strengthened their eyalets on the conquered territories, including the Budin Eyalet. Out of fear that, with the conquest of the southern regions, the Ottomans would also try to establish new eyalets there and by doing so weaken the monarchy, the Provincial Estates of Carniola warned Emperor Ferdinand (1521-1564) of the poor condition of the fortresses in the southern Slavic regions and demanded that they be strengthened (Mantuani 1937). Fortresses were no longer sufficient for defence against the Ottomans, especially because of changes in the strategy of warfare and new military technology, especially artillery (Figure 9). 


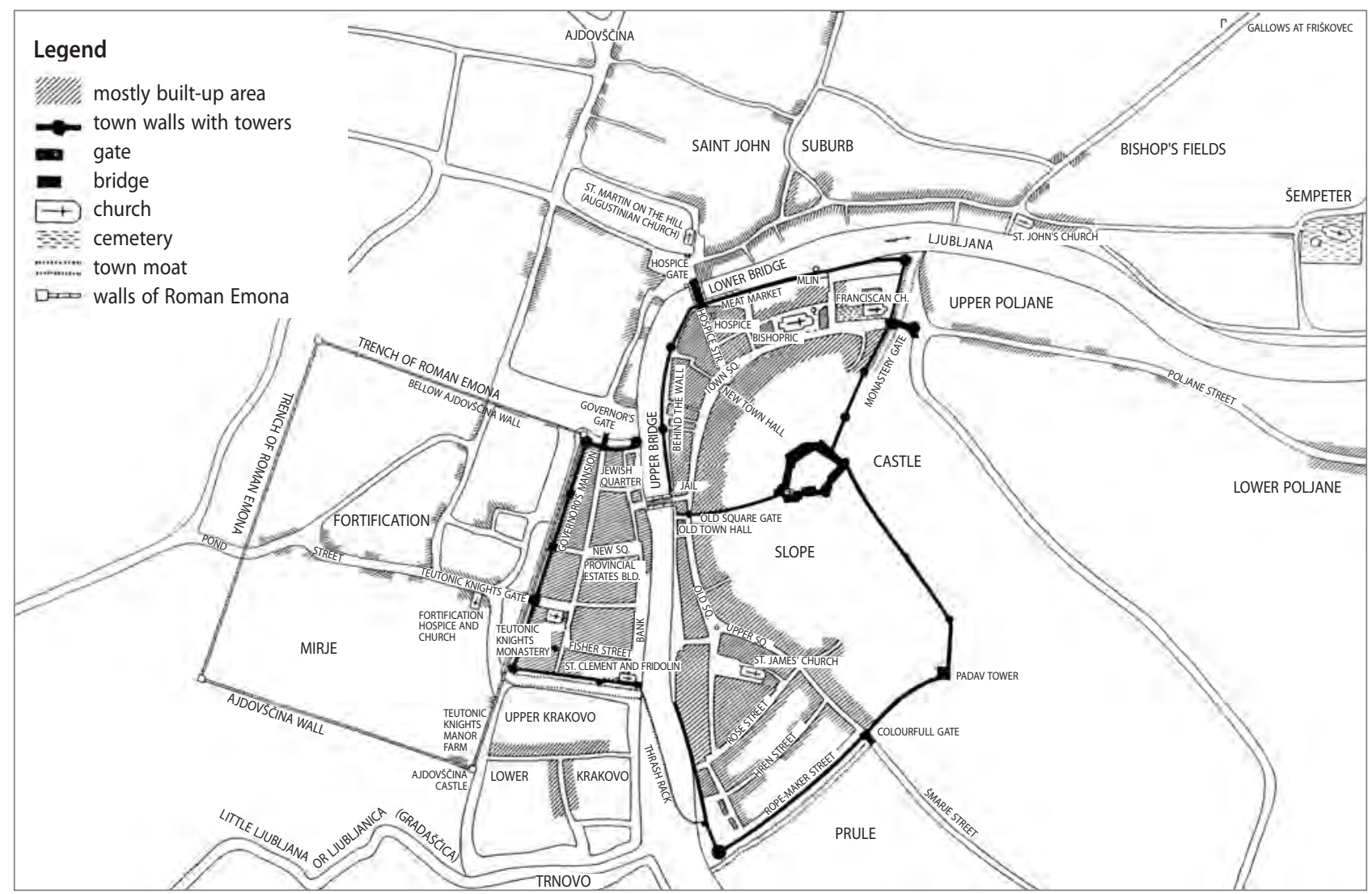

Figure 9: Ljubljana in the Middle Ages (Old Square, New Square and Town Square; source: Kos, 1955).

The Viennese government sent a royal military committee to inspect the area. The committee comprised experts for strategic urban defence led by the Italian architect Giovanni Pieroni, who was a well-known builder of fortification structures at that time. In 1638, the committee visited the fortress in Karlovac and other fortified towns in the Military Frontier, as well as Ljubljana. In a pen-and-ink drawing, Pieroni designed a layout of the town with a fortress on the castle grounds and the entire town wall. However, this design was never used. Almost two decades later, in 1657, another military expert committee for strategic urban defence was sent from Vienna to the southern regions. This was led by the royal engineer Martin Stier (Mantuani, 1937; Tomažič, 1937; Voje, 1984). The committee members wrote four reports that included maps and layouts of towns and fortresses in order to inform Emperor Leopold (1658-1705) of the current state of affairs. The second and the third reports are the most important for Ljubljana because they include a layout of Ljubljana, data about its size, forts, squares, roads and streets as well as a description of the town's military condition (the number of cannons, other weapons and ammunition). From the standpoint of Ljubljanass strategic urban defence, the reports found that only the castle was protected in the case of a war, whereas the rest of the town on the Ljubljanica's left and right banks was completely exposed and supposedly absolutely unprepared for defence. In his sug- gestion, which considered options for strategic urban defence, Stief discussed how to prepare Ljubljana for a three-month siege and defined two levels of protection. The first level included protecting the closest suburban settlements, from the Fortification area (Sln. Gradišce) in the south to the present Tavčar Street in the north and from the Ljubljanica River in the east to the present Prešeren Street in the west. He envisioned the area being protected with embankments of soil with spikes. The second level included the renewal of the forts. He planned to build a pier (bastion) outside the town walls in Old Square between the sluices and Karlovac Street that he called neues Werk 'new construction'. A similar solution was envisioned for the transverse fort on Castle Hill known as Planišce. For New Square he suggested that the old walls be additionally fortified with embankments and, in line with strategic urban defence, additional piers with bastions be built to ensure greater protection. Around the settlement he planned to build tunnels that would be filled with water from the Gradaščica River. Even though the Ottoman raids in Slovenian towns were not as frequent after their defeat at Vienna in 1683, in 1717 barracks for 500 soldiers were built at Frog Pond Street (Sln. Žabjak) in New Square. This later became unsuitable and was turned into a jail in 1754 (today a residential building at Hren Street, Sln. Hrenova ulica, no. 17; see Šarac, 2009). At the end of the eighteenth century, when the fortification process in the 
Military Frontier was finished, the triple settlement core slowly started to expand outside the town walls as well. Because the maintenance of the town walls became too expensive and the walls increasingly obstructed expansion and communication, in 1787 the provincial administration ordered the Municipality of Ljubljana to start demolishing the town walls because they had lost their defensive purpose (Wester, 1934). With the removal of the fortification walls that limited the town's spatial and urban development for centuries, Ljubljana became an open town and its surrounding outskirts gradually became part of its administrative and urban-planning network (Melik, 1929-1930; Mihelič, 1983).

\section{Conclusion}

Historical studies show that people have been thinking about protection and defence ever since they first started building settlements; that is, from first human encroachment into the environment (in prehistory), when they stopped looking for natural shelters instinctively and consciously started building and living in them. It is not difficult to see that throughout historical development in space human self-protection has always been expressed in various ways. In fact, this has to do with various measures that people used to protect themselves from wars and in this article they are referred to as strategic urban defence. Above all, this depended on natural conditions (location) but also on the strategic resourcefulness and imagination of individuals in the urban and architectural sense as well as on weapons and other means that were constantly altered throughout history and from war to war. In human historical development there were always people that had an innate talent for warfare (Alexander the Great, Attila and others) as well as for collective self-protection; that is, strategic urban defence. The case of Ljubljana shows that by the Middle Ages there were military experts in architecture and construction that were in charge of ensuring greater effectiveness in implementing strategic urban defence. Until very recently, similar experts in strategic urban defence were in charge of constructing public fallout shelters. A historical, archaeological, geographic, urban and architectural overview of the modern Ljubljana area showed that here as well principles of strategic urban defence have been used continually from prehistory until today. However, because they have not been sufficiently studied in the existing literature on urbanism and architecture of Ljubljana, all important findings in this research relating to strategy in a larger area had to be analysed and compared and then new conclusions had to be drawn based on new findings. The most important question was whether Ljubljana's first settlement core (Old Square) was established by coincidence. The analysis clearly showed that the settlement was established at this location originally as a farming and military settlement and that the decision to select this location was primarily influenced by military reasons and principles of strategic urban defence. Ljubljanass third settlement core (Town Square) was also developed according to the principles of strategic urban defence, albeit under different historical circumstances. Although the Ljubljanica's left bank had all the necessary urban prerequisites for the town's development, the better security and strategic conditions on the right bank were the main reason why the city continued to develop in this location. These natural conditions proved to be important in wars with the Ottomans in the following centuries.

The research findings are significant because they provide clear and more detailed information from a military perspective, which has not been taken into account to date: they provide insight into the origin of Ljubljana, its strategic urban defence and the urban development of old Ljubljana during its two centuries under siege. They are also useful for further research on Ljubljana from the military aspect and as a model for studying other Slovenian towns and, finally, they are also an important part of cultural heritage.

\section{Darko Šarac}

Ljubljana, Slovenia

E-mail:darko.sarac@gmail.com

\section{Acknowledgements}

I would like to thank my advisor Živa Deu for encouragement and guidance in writing this article, Boštjan Kerbler for suggestions on systemising and technically preparing this article, as well as proofreader Nina Novak.

\section{References}

Bergant, T. (1984) Novi rezultati raziskav ljubljanskega barja. In: Gestrin, F. (ed.): Zgodovina Ljubljane. Prispevki za monografijo, pp. 23-27. Ljubljana, Zgodovinsko društvo.

Bleiken, J. (1976) Svetovna zgodovina, od začetka do danes. Ljubljana, Cankarjeva založba.

Bogdanov, N., Grlić, D., Iveković, M., Krstić, K., Podhorsky, R. \& Vranjican, B. (eds.) (1967) Enciklopedija leksikografskog zavoda, vol. 2, pp. 368-370. Zagreb, Jugoslavenski leksikografski zavod.

Bogdanović, B. (1976) Urbs \& logos: ogledi iz simbologije grada. Niš, Gradina.

Bratož, R. (1984) Krščanska Emona in njen zaton. In: Gestrin, F. (ed.): Zgodovina Ljubljane. Prispevki za monografijo, pp. 64-71. Ljubljana, Zgodovinsko društvo.

Cevc, E. (1984) Likovna umetnost v srednjeveški Ljubljani. In: Gestrin, F. (ed.): Zgodovina Ljubljane. Prispevki za monografijo, pp. 96-102. Ljubljana, Zgodovinsko društvo.

Ciglenečki, S. (1992) Polis Norikon. Podsreda, Tiskarna Povše.

Fister, P. (1986) Umetnost stavbarstva na Slovenskem. Ljubljana, Cankarjeva založba. 
Gestrin, F. (1984) Ljubljana v 16. in 17. stoletju. In: Gestrin, F. (ed.): Zgodovina Ljubljane. Prispevki za monografijo, pp. 105-120. Ljubljana, Zgodovinsko društvo.

Grafenauer, B. (1963) Ljubljana v srednjem veku. Kronika: časopis za slovensko krajevno zgodovino, 11(3), pp. 129-139.

Gruden, J. (1992) Zgodovina slovenskega naroda. Celje, Mohorjeva družba.

Javornik, M. (ed.) (1998) Veliki splošni leksikon. Ljubljana, Mladinska knjiga.

Keegan, J. (2005) Zgodovina vojskovanja. Ljubljana, Fakulteta za družbene vede.

Korošec, B. (1991) Ljubljana skozi stoletja: mesto na načrtih, projektih in v stvarnosti. Ljubljana, Mladinska knjiga.

Kos, M. (1955) Srednjeveška Ljubljana. Ljubljana, Tiskarna Toneta Tomšiča.

Kos, M. (1985) Srednjeveška zgodovina Slovencev. Ljubljana, Slovenska matica.

Košir, F. (1993) Zamisel mesta. Ljubljana, Slovenska matica.

Maksimović, B. (1972) Istorija urbanizma. Belgrade, Naučna knjiga.

Mantuani, J. (1937) Najstarejši načrt Ljubljane. Kronika slovenskih mest, 4(3), pp. 161-165.

Melik, A. (1929-1930) Razvoj Ljubljane. Geografski vestnik, 5-6, pp. 93138.

Mihelič, B. (1983) Urbanistični razvoj Ljubljane. Ljubljana, Znanstveni institut Filozofske fakultete.

Mumford, L. (1969) Mesto v zgodovini. Ljubljana, Državna založba Slovenije.

Plesničar-Gec, L. (1984) Arheološka obdobja Ljubljane. In: Gestrin, F. (ed.): Zgodovina Ljubljane. Prispevki za monografijo, pp. 11-20. Ljubljana, Zgodovinsko društvo .

Puš, I. (1984) Ljubljanski prostor v starejši železni dobi. In: Gestrin, F. (ed.): Zgodovina Ljubljane. Prispevki za monografijo, pp. 35-45. Ljubljana, Zgodovinsko društvo.

Reisp, B. (1998) Gradovi dežele Kranjske. Ljubljana, Slovenska matica. Šarac, D. (2009) Vojaški kompleksi v Ljubljani in njihova sprememba skozi čas. Master's thesis. Ljubljana, Fakulteta za gradbeništvo in geodezijo.

Šarac, D. (2013): Vpliv vojsk na prostorski in urbanistični razvoj mesta Ljubljana [The army's influence on the spatial and urban development of the city of Ljubljana]. Typescript.

Šašel, J. (1984) K zgodovini Emone v rimskih napisih in literaturi. In: Gestrin, F. (ed.): Zgodovina Ljubljane. Prispevki za monografijo, pp. 28-34. Ljubljana, Zgodovinsko društvo.

Schmid, W. (1941) Emona ni bila vojaški tabor. Glasnik Muzejskega društva za Slovenijo, 22(1-2), pp. 44-54.

Šenica-Pavletič, V. (2005) Zgodba o Ljubljanskem gradu. Ljubljana, Karantanija.

Simoniti, P. (1984) H kulturnozgodovinski podobi Ljubljane v 16. stoletju. In: Gestrin, F. (ed.): Zgodovina Ljubljane. Prispevki za monografijo, pp. 121-124. Ljubljana, Zgodovinsko društvo.

Simoniti, V. (1990) Turki so v deželi že. Celje, Mohorjeva družba.

Sivec, I. (1984) Ljubljana v zgodnjem srednjem veku. In: Gestrin, F. (ed.): Zgodovina Ljubljane. Prispevki za monografijo, pp. 69-71. Ljubljana, Zgodovinsko društvo.
Slabe, M. (1984) Poskus prikaza poselitve v Ljubljanski kotlini (5. in 6. stoletje ). In: Gestrin, F. (ed.): Zgodovina Ljubljane. Prispevki za monografijo, pp. 57-63. Ljubljana, Zgodovinsko društvo.

Stele, F. (1939) Zemljepisni in zgodovinski pogoji srednjeveške Ljubljane. Kronika slovenskih mest, 4(6), pp. 49-51.

Šumi, N. (1953) Ob novem predlogu generalnega načrta za Ljubljano. Kronika slovenskih mest, 1(3), pp. 201-204.

Tancik, F. (1971) Orožje in bojna oprema od naselitve Slovencev do konca 17. stoletja. Ljubljana, Narodni muzej.

Tomažič, F. (1937) Talni načrt mesta Ljubljana. Kronika slovenskih mest, 4(2), pp. 88-103.

Tomažič, F. (1938) Vojna in mesto. Kronika slovenskih mest, 5(2), pp. 7893.

Valvasor, J. V. (1984) Slava vojvodine Kranjske. Ljubljana, Mladinska knjiga.

Vilfan, S. (1956) Nekaj vprašanj iz zgodovine Stare Ljubljane. Kronika: časopis za slovensko krajevno zgodovino, 4(3), pp. 132-148.

Vilfan, S. (1984) Zgodovina Ljubljane do začetka 16. stoletja. In: Gestrin, F. (ur.): Zgodovina Ljubljane. Prispevki za monografijo, pp. 75-95. Ljubljana, Zgodovinsko društvo.

Voje, I. (1984) Analiza načrtov Ljubljane iz 16. in 17. stoletja. In: Gestrin, F. (ed.): Zgodovina Ljubljane. Prispevki za monografijo, pp. 140-154. Ljubljana, Zgodovinsko društvo.

Wester, J. (1934) Momenti v razvoju Ljubljane od leta 1787 do 1821. Kronika slovenskih mest, 1(1), pp. 23-27.

Žontar, J. (1984) Ljubljana v 18. in v prvi polovici 19. stoletja. In: Gestrin, F. (ed.): Zgodovina Ljubljane. Prispevki za monografijo, pp. 157176. Ljubljana, Zgodovinsko društvo.

Zwitter, F. (1929-1930) Razvoj ljubljanskega teritorija. Geografski vestnik, 5-6, pp. 138-154. 